Argonne Rational Laboratom

PREPARATION OF ALLOY FOR

FIRST CORE LOADING

$$
\text { OF EBR-II }
$$

by

Donald C. Hampson 


\section{DISCLAIMER}

This report was prepared as an account of work sponsored by an agency of the United States Government. Neither the United States Government nor any agency Thereof, nor any of their employees, makes any warranty, express or implied, or assumes any legal liability or responsibility for the accuracy, completeness, or usefulness of any information, apparatus, product, or process disclosed, or represents that its use would not infringe privately owned rights. Reference herein to any specific commercial product, process, or service by trade name, trademark, manufacturer, or otherwise does not necessarily constitute or imply its endorsement, recommendation, or favoring by the United States Government or any agency thereof. The views and opinions of authors expressed herein do not necessarily state or reflect those of the United States Government or any agency thereof. 


\section{DISCLAIMER}

Portions of this document may be illegible in electronic image products. Images are produced from the best available original document. 


\section{LEGAL NOTICE}

This report was prepared as an account of Government sponsored work. Neither the United States, nor the Commission, nor any person acting on behalf of the Commission:

A. Makes any warranty or representation, expressed or implied, with respect to the accuracy, completeness, or usefulness of the information contained in this report, or that the use of any information, apparatus, method, or process disclosed in this report may not infringe privately owned rights; or

B. Assumes any liabilities with respect to the use of, or for damages resulting from the use of any information, apparatus, method, or process disclosed in this report.

As used in the above, "person acting on behalf of the Commission" includes any employee or contractor of the Commission, or employee of such contractor, to the extent that such employee or contractor of the Commission, or employee of such contractor prepares, disseminates, or provides access to, any information pursuant to his employment or contract with the Commission, or his employment with such contractor.

Price 50 cents. Available from the office of Technical Services, Department of Commerce, Washington 25, D.C. 
ANL-6290

Metals, Ceramics, and Materials

(TID-4500, 16th Ed. , Amended)

AEC Research and

Development Report

\section{ARGONNE NATIONAL LABORATORY \\ 9700 South Cass Avenue \\ Argonne, Illinois}

PREPARATION OF ALLOY FOR FIRST CORE LOADING OF EBR-II

by

Donald C. Hampson

Chemical Engineering Division

August 1961

Operated by The University of Chicago under

Contract W-3l-109-eng-38 
TABLE OF CONTENTS

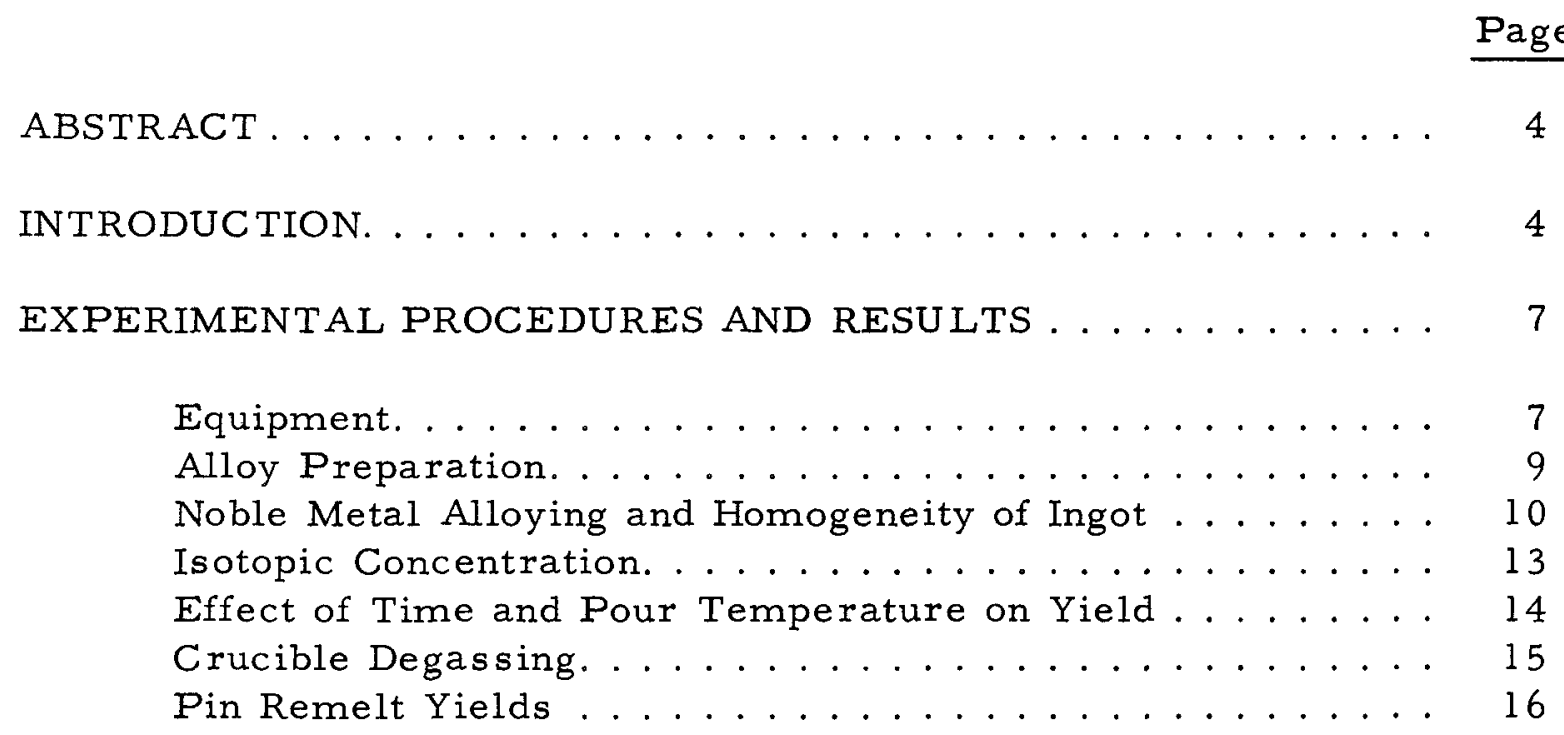

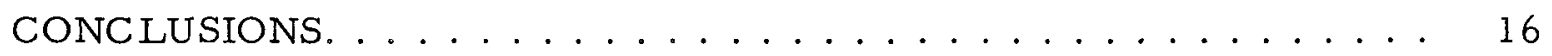

ACKNOW LEDGMENTS . . . . . . . . . . . . . . . . . . . . 16

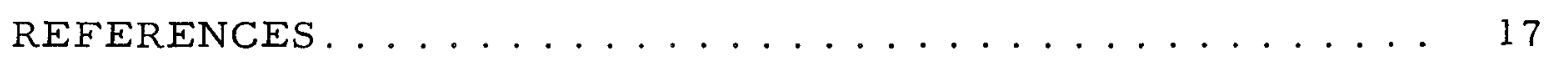




\section{LIST OF FIGURES}

No.

Title

Page

1. EBR-II Fuel Cycle Facility, Main Floor........... 6

2. Melt-refining Furnace, Pouring Position .......... 8

\section{LIST OF TABLES}

No.

Title

$\underline{\text { Page }}$

1. Composition of EBR-II Fuel Alloy .............. 6

2. Summary of Ingot Production ................ 9

3. Homogeneity of DL Ingots ................. 11

4. Degree of Alloying of Elements in DL Fissium Ingots..... 11

5. Enrichment of Fuel Alloy................. 13

6. Isotopic and Chemical Composition of Enriched Fissium

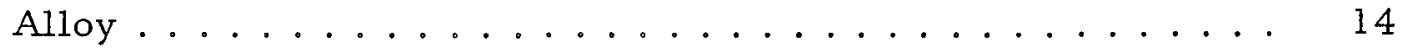

7. Effect of Liquation Time on Yield ............ 15

8. Effect of Pour Temperature on Yield........... 15 


\title{
PREPARATION OF ALLOY FOR FIRST CORE LOADING OF EBR-II
}

by

Donald C. Hampson

\begin{abstract}
The alloy used for the fabrication of the fuel pins for the first core loading of the second Experimental Breeder Reactor (EBR-II) was prepared in the prototype equipment developed for the melt-refining processing of the irradiated EBR-II fuel. One hundred and twenty-five $10-\mathrm{kg}$ ingots were made, of which 40 were unenriched uranium-fissium alloy and 85 were enriched uranium-fissium alloy. In addition, nineteen $10-\mathrm{kg}$ batches of unenriched uranium-fissium scrap and forty-seven $10-\mathrm{kg}$ batches of enriched uranium-fissium alloy scrap were melted for consolidation into ingots. The average yield for the alloy preparation runs was 96.5 percent and for the scrap remelt runs was 93 percent. The chemical and isotopic compositions of the ingots produced were all within specifications $(95 \pm 1.0 \mathrm{w} / 0$ uranium, of which $48.1 \pm 1.2 \mathrm{w} / \mathrm{o}$ is $\mathrm{U}^{235}$ ).
\end{abstract}

\section{INTRODUCTION}

The second Experimental Breeder Reactor (EBR-II) complex is 10cated at the National Reactor Testing Station in Idaho. This complex, designed by Argonne National Laboratory, consists of the reactor, power plant, and an integrated fuel-reprocessing plant. The reactor is an unmoderated, heterogeneous, sodium-cooled reactor with a design capacity of $62.5 \mathrm{Mw}$ of heat. This heat is converted to $20 \mathrm{Mw}$ of electricity through a conventional steam cycle. The initial loading of the reactor consists of a uranium (50 percent enriched)-fissium* alloy. Later loadings may change in enrichment or by substitution of plutonium for a portion of the uranium.

The fuel will remain in the reactor for about 135 days, during which time about 2 percent of the atoms in the fuel will be consumed and converted by fission to fission products. After removal from the reactor core, the irradiated fuel-element subassemblies are stored in the sodium-cooled

*Fissium is a general name given to a variable mixture of fission product elements (atomic numbers 40 to 47 ), which, when alloyed with uranium, impart to the alloy desirable metallurgical and radiationstability properties. 
reactor tank for 15 days to prevent melting of the fuel because of heat produced by internal fission products. The fuel is then processed in the Fuel Cycle Facility (FCF) which is an integral part of the reactor complex.

In the Fuel Cycle Facility, the fuel subassemblies are dismantled and the individual fuel elements are decanned to remove the thin stainless steel can from the fuel pins.. These fuel pins a re about $36 \mathrm{~cm}$ (14.22 in.) long, $0.37 \mathrm{~cm}$ (0.144 in.) in diameter, and weigh about $70 \mathrm{gm} \mathrm{each}$. After chopping to $4-\mathrm{cm}(1.5$-in.) lengths, about $10 \mathrm{~kg}$ of the pins are loaded into a ceramic crucible for melt refining. The purified metal is separated from the oxide dross, which is formed during melt refining, by pouring the metal from the crucible into a graphite mold. The oxide dross forms a tightly adhering film on the crucible wall and remains in the crucible when the metal is poured. The resultant ingot is recast into fuel pins by an injection-casting process. The fuel pins are inspected, canned and bonded, and assembled into subassemblies. These subassemblies are then recycled to the reactor for subsequent core loadings.

The melt-refining process consists of liquating the molten alloy $(\mathrm{mp} 1020-1050 \mathrm{C})$ for periods up to $4 \mathrm{hr}$ at $1400 \mathrm{C}$. The decontamination of the fuel is accomplished by three mechanisms in the melt-refining process. (1) (1) The inert fission product gases xenon and krypton a re released from the metal during the heating and melting cycle. (2) The lower boiling elements are volatilized from the molten fuel. They are trapped and confined in a fume trap which sits on top of the crucible during the melt-refining process. These condensable elements include bromine, iodine, cesium, rubidium, and cadmium. (3) The elements which are more reactive than uranium react with the oxygen of the crucible to form a high-melting oxide dross or slag layer. These elements are mainly in the rare earth series. The elements which are removed by a combination of these processes comprise about two-thirds of the fission products generated during each reactor cycle.(2)

The resultant steady-state concentrations of noble metals in recycled fuel can be calculated as functions of fission yield, percent burnup, melt-refining reactions, and yields.(3) To avoid dealing with a fuel of changing composition, it is desirable to start with a fuel having an equilibrium or steady-state noble metal concentration. The composition of the uranium-fissium alloy that was chosen for the initial or first core loading of EBR-II is shown in Table 1 .

The Fuel Cycle Facility (see Figure 1) consists of two heavily shielded, interconnected cells. (4) The first is a rectangular cell with an air atmosphere and is serviced by master-slave and electromechanical manipulators and an overhead crane. All the disassembly, reassembly, and testing operations with the canned fuel elements and fuel subassemblies 
will be conducted in this area. The other cell is a circular (actually a 16-sided polygon) cell containing a shielded toroidal-shaped process a rea. An inert atmosphere* will be maintained in this area, which will be used for the fuel-purification and refabrication process. This area is serviced by six electromechanical manipulators and two overhead cranes. The requirement of sealing the cell to maintain the inert atmosphere precludes the use of any presently available through or over-the-wall types of manipulators.

Table 1

COMPOSITION OF EBR-II FUEL ALLOY

\begin{tabular}{lc}
\multicolumn{1}{c}{ Element } & Weight Percent \\
Uranium & 95.00 \\
$\mathrm{U}^{235}-45.72$ percent & \\
$\mathrm{U}^{238}-49.28$ percent & \\
Molybdenum & 2.46 \\
Ruthenium & 1.96 \\
Rhodium & 0.28 \\
Palladium & 0.19 \\
Zirconium & 0.10 \\
Niobium & 0.01 \\
& 100.00
\end{tabular}

Figure 1

EBR-II FUEL CYCLE FACILITY, MAIN FLOOR

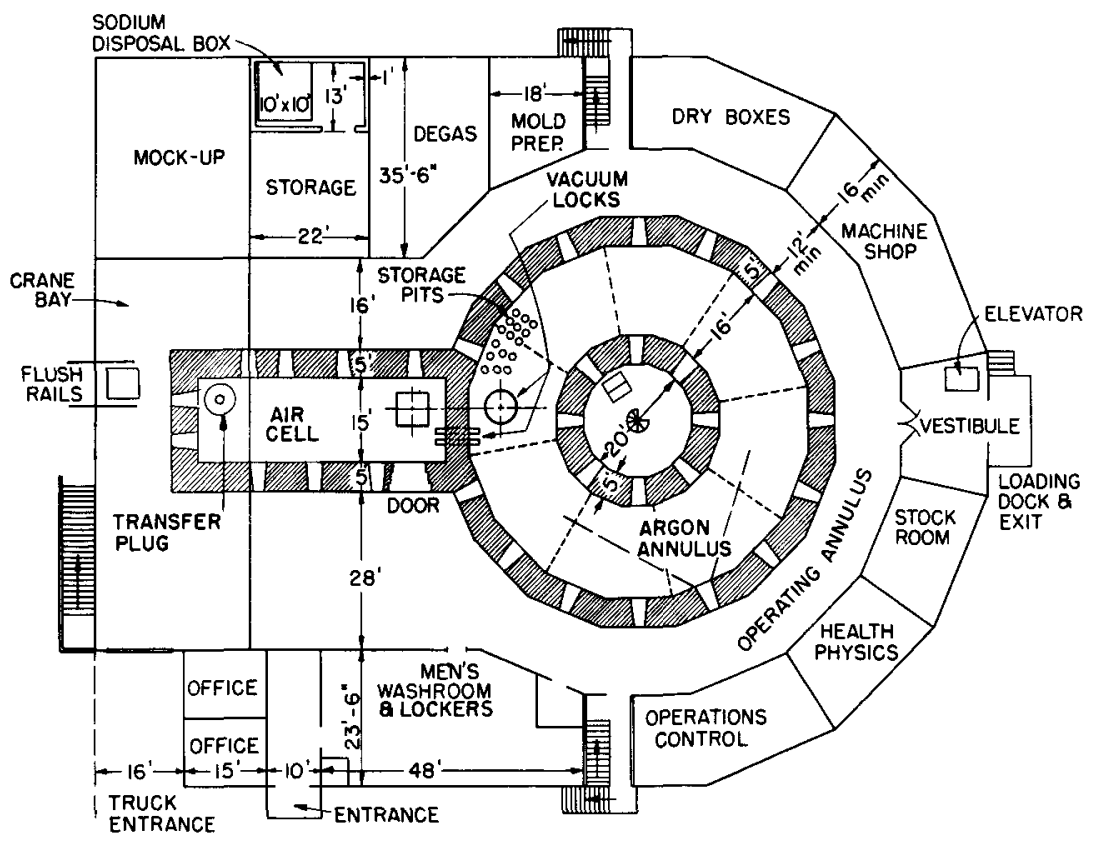

* The inert atmosphere will be essentially argon, less than 5 percent nitrogen, less than $100 \mathrm{ppm}$ oxygen, and less than 5 ppm water. 
All leads into the cell are sealed to the cell wall to prevent leakage of air into the cell or contamination out of the cell into the operating area.

The melt-refining and auxiliary equipment are designed to be operated wholly by the electromechanical manipulators. Other pieces of equipment in the Argon Cell are designed to be operated by electrical means or argon-operated pneumatic devices. A means of visual observation of the operation of the equipment is provided by large shielding windows.

In order to test the many new concepts that are being incorporated in the Fuel Cycle Facility and in the process equipment, a full-scale mockup of a 45-degree segment of the circular cell has been built. It has been furnished with prototypes of the viewing window, manipulator, lighting, and melt-refining equipment. For practical reasons, the atmosphere is ordinary air, rather than a dry inert atmosphere, and no radiation is present.

The mockup area and the prototype melt-refining equipment were utilized for the production of the alloy to be used in the first core of EBR-II. The production of the alloy provided an excellent opportunity to simulate the conditions for the entire melt-refining operations that will occur in the Fuel Cycle Facility. Moreover, the fuel-processing runs not only provided an important means of personnel training, but also served to develop and improve operating procedures and techniques. Modifications of the equipment were made and tested in this final phase of equipment shakedown prior to installation of the equipment in the Fuel Cycle Facility.

\section{EXPERIMENTAL PROCEDURES AND RESULTS}

Equipment

The furnace (Figure 2) used in the alloy preparation runs has been described in detail elsewhere.(5) In brief, the metal is melted and liquated in a lime-stabilized, pressed zirconium oxide crucible which is situated inside a graphite susceptor. The susceptor and, consequently, the crucible are heated by a 5 -turn, $\frac{1}{2}$-in. diameter, solid, uncooled copper induction coil. The induction power is 10,000 cycle - 220 volt. The susceptor is the rmally and electrically insulated from the coil by silicon carbide grain contained in a Fiberfrax* outer sleeve. An inverted Fiberfrax cylinder is located on the top of the crucible during the heating and liquating phase of the melt-refining operation. This serves the dual function of insulating the

*A ceramic fiber made of alumina and silica by the Carborundum Company. 
top of the crucible and trapping the volatile constituents that are released in melt refining. The furnace is tilted for pouring by means of a rack and gear. The metal is poured into a graphite mold.

Figure 2

\section{MELT-REFINING FURNACE - POURING POSITION}

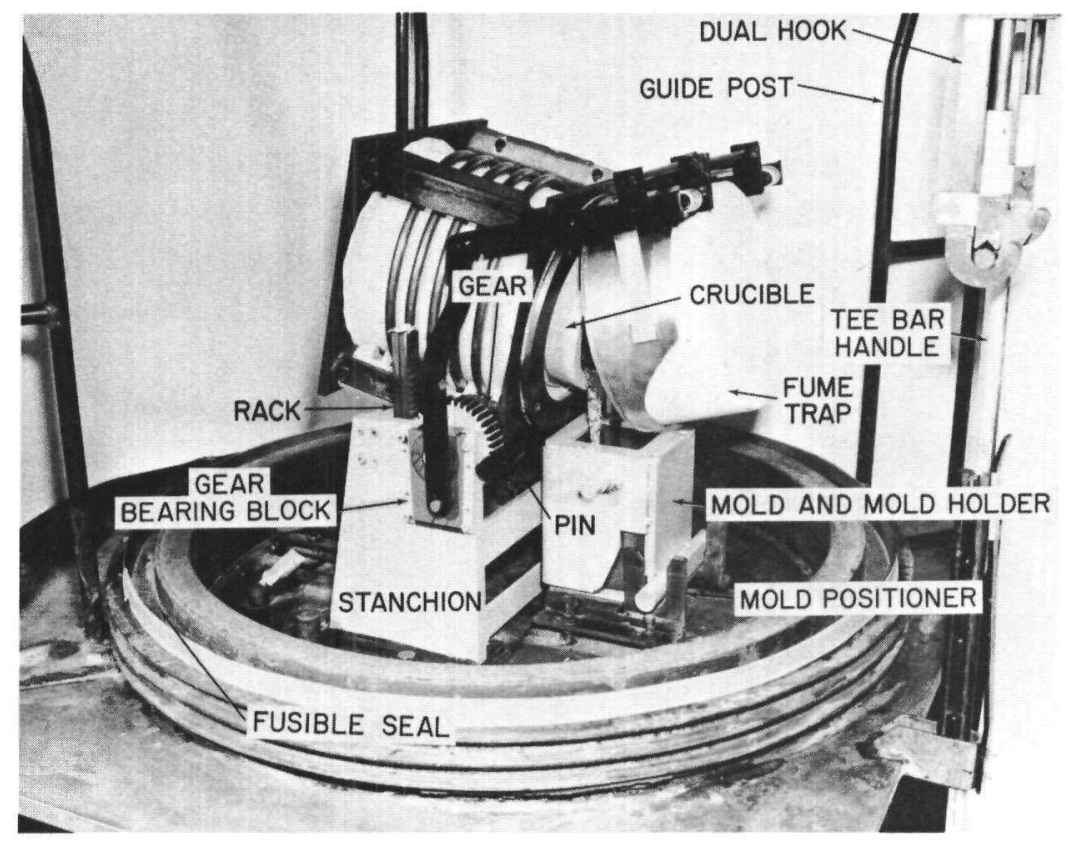

The entire furnace is enclosed by a steel bell jar which is sealed to the base plate of the furnace during the heating and cooling cycle. The melts were made under one atmosphere of argon. When not in use, the furnace was normally covered by the bell jar in which an argon atmosphere was maintained. If the furnace stood open in the air for any appreciable time, or if new componenents were introduced into the system, the furnace was degassed at operating temperatures and one mm Hg pressure for 4 to $8 \mathrm{hr}$ prior to its use for alloy preparation.

The operation of the furnace, except for charging, was accomplished by use of a manipulator(6) that is the prototype of the manipulators being built for use in the Fuel Cycle Facility. The manipulator consists of a carriage with a vertical telescoping arm terminating in a grip or hand mechanism. The carriage travels on a bridge that is pivoted at the center of the cell and rotates around the cell. The hand or grip mechanism, in addition to its opening or closing motion, can rotate continuously in either direction. The manipulator has a 750-lb lifting capacity. Viewing was accomplished by use of a prototype(7) 5 -foot thick window. 
Alloy Preparation

The fuel-production program was divided into two phases: (1) the preparation of unenriched alloy and (2) the preparation of enriched alloy. The series of runs for the production of unenriched alloy was used for the testing of procedures and equipment. The alloy prepared had the same chemical composition as the first core alloy (see Table 1). The pins cast from this alloy were fabricated for use in the precritical loading of the reactor and for various physical and metallurgical tests. This series was designated as the dummy-load series, and the run numbers were prefaced by the initials "DL." The production of series for enriched uraniumfissium alloy was designated as the first-core loading series, and the runs were identified by the preface "FC."

The scrap and pin ends that resulted from injection-casting pins from these series were remelted. These pin-remelt runs more closely simulated the physical conformation of actual melt-refining runs that did the alloy preparation. The pin-remelt runs were coded DLP and FCP for dummy-load pins and the first-core pins, respectively. The DL and DLP series were used to determine the desirable operating conditions, which were then used as the basis of the conditions for FC and FCP runs.

In the four series, a total of 191 ten-kg runs were made. The distribution of the runs between the four series and the pouring yields obtained are summarized in Table 2 .

Table 2

\section{SUMMARY OF INGOT PRODUCTION}

\begin{tabular}{|c|c|c|c|c|c|c|}
\hline \multirow[b]{2}{*}{ Series } & \multirow[b]{2}{*}{$\begin{array}{l}\text { Number } \\
\text { of Runs }\end{array}$} & \multirow{2}{*}{$\begin{array}{l}\quad \text { Avg } \\
\text { Pouring } \\
\text { Yield, \% }\end{array}$} & \multirow{2}{*}{$\begin{array}{c}\text { Total } \\
\text { Weight } \\
\text { of Ingots, } \\
\text { kg }\end{array}$} & \multicolumn{3}{|c|}{$\begin{array}{c}\text { Composition } \\
\text { (Weight Percent*) }\end{array}$} \\
\hline & & & & $\mathrm{U}$ & $\mathrm{U}^{235}$ & Fissium \\
\hline $\mathrm{DL}$ & 40 & 95.8 & 418 & 95 & - & 5 \\
\hline DLP & 19 & 93.5 & 178 & 95 & - & 5 \\
\hline$F C$ & 85 & 96.8 & 859 & 95 & 45.6 & 5 \\
\hline $\mathrm{FCP}$ & 47 & 92.5 & 437 & 95 & 45.6 & 5 \\
\hline Total & 191 & & 1892 & & & \\
\hline
\end{tabular}

*Nominal composition $95 \% \mathrm{U}-5 \%$ Fissium. Of the $95 \% \mathrm{U}$ in the FC runs, $45.6 \%$ is $\mathrm{U}^{235}$, and $49.4 \%$ is $\mathrm{U}^{234}, \mathrm{U}^{236}$, and $\mathrm{U}^{238}$. 
Because the densities of the alloying elements are less than the density of uranium, there is a tendency for them to float on the melt. As a result, there is a greater chance of a reaction of the alloying elements with impurities in the atmosphere or of loss of alloying element to the dross slag. Therefore, the method of charging the alloying elements was to place them in the bottom of the crucible and to weight them down with the larger pieces of uranium. It has been shown $(8)$ that placing zirconium and niobium below the uranium charge, rather than on top, approximately doubles the amount of the element which alloys with the uranium under the same operating conditions. A new crucible was used for each run.

The uranium used for the preparation of enriched alloy was in two forms. The enriched portion was in the form of broken pieces of buttons (6-in. diamete $\mathrm{r} \times 1$-in. thickness prior to breaking) of uranium enriched to greater than 90 percent in $\mathrm{U}^{235}$. The diluent uranium was in the form of cubes and slabs $\left(\frac{1}{2}\right.$ to 2 in. on a side) of 1.44 percent enriched metal. These two enrichments of starting material were used because they were readily available in the desired purity.

The molybdenum used was in the form of pieces of $\frac{1}{8}$-in.-thick plate or in the form of sintered pressed pellets. Ruthenium, rhodium, palladium, and niobium were in the form of sintered pressed pellets. The zirconium used was in small lengths, cut from crystal bar zirconium.

Noble Metal Alloying and Homogeneity of Ingot

The first variables that were investigated in the DL series of runs were of alloying of the noble metals with the uranium and the degree of homogeneity of the ingot. The reliability of the method of sampling was also investigated. Preliminary tests had shown that the composition of a protrusion cast on the base of the ingot was representative of the composition of the whole ingot. These tests were made with iron as a contaminant in a uranium ingot. Iron was used because it was more likely to segregate (because of fractional crystallization) than any of the fissium elements. The concentration of the iron in the test protrusion samples varied from the concentration of iron in the ingot by less than 2 percent.

The first eight of the DL series ingots were sampled in four locations as follows: the protrusions cast on the base of each ingot, and slices taken from the top, middle, and bottom of the ingot. The analyses shown in Table 3 indicate that the ingots were homogeneous and confirmed the expectation that the protrusion samples were representative of the ingot composition.

The degree to which each individual noble metal alloyed with the uranium matrix is shown in Table 4. Also shown in this table is a comparison of the analytical results obtained from three separate analytical techniques that were used on the protrusion samples. 
Table 3

HOMOGENEITY OF DL INGOTS

Percent of Nominal Composition

\begin{tabular}{|c|c|c|c|}
\hline Mo & $\mathrm{Ru}$ & $\mathrm{Pd}$ & $\mathrm{Zr}$ \\
\hline $97.6 \pm 5.5^{a}$ & $101.3 \pm 2.6$ & $94.6 \pm 6.9$ & $85.5 \pm$ \\
\hline $99.0 \pm 4.6$ & $101.4 \pm 2.7$ & $93.8 \pm 7.7$ & $74.6 \pm 7.1$ \\
\hline $97.0 \pm 6.6$ & $102.8 \pm 3.6$ & $94.9 \pm 7.2$ & $76.1 \pm 10.6$ \\
\hline $97.8 \pm 5.5$ & $101.8 \pm 2.9$ & $94.4 \pm 7.2$ & $78.7 \pm 8.2$ \\
\hline $98.7 \pm 2.4$ & $101.0 \pm 1.4$ & $93.4 \pm 7.6$ & $80.8 \pm 10.5$ \\
\hline
\end{tabular}

a All values of uncertainty of determinations used in this report are based on the equation

$$
\sigma=\sqrt{\frac{\sum \mathrm{d}^{2}}{\mathrm{n}-1}}
$$

where $\sigma$ is the degree of uncertainty and $d$ is the deviation of the individual determination from the average of $\mathrm{n}$ determinations.

Table 4

\section{DEGREE OF ALLOYING OF ELEMENTS IN \\ CAST DL FISSIUM INGOTS}

\begin{tabular}{|c|c|c|c|c|}
\hline \multirow[b]{2}{*}{ Element } & \multirow[b]{2}{*}{$\begin{array}{l}\text { Nominal } \\
\text { Composi- } \\
\text { tion, w/o }\end{array}$} & \multicolumn{3}{|c|}{ Percent of Nominal Composition } \\
\hline & & $\begin{array}{c}\text { Spectrophotom - } \\
\text { etry }\end{array}$ & $\begin{array}{l}\text { Emission } \\
\text { Spectrog- } \\
\text { raphy }\end{array}$ & $\begin{array}{c}\text { X-ray } \\
\text { Eluores- } \\
\text { cence }\end{array}$ \\
\hline Molybdenum & 2.46 & $96.1 \pm 2.5$ & $95.9 \pm 4.2$ & $97.2 \pm 2.4$ \\
\hline Ruthenium & 1.96 & $99.0 \pm 2.5$ & $103.7 \pm 1.9$ & $98.1 \pm 1.8$ \\
\hline Rhodium & 0.28 & - & $97.0 \pm 3.9$ & - \\
\hline Palladium & 0.19 & $99.0 \pm 3.2$ & $97.4 \pm 3.8$ & - \\
\hline Zirconium & 0.10 & $86.2 \pm 11.9$ & - & $83.7 \pm 9.5$ \\
\hline \multirow[t]{2}{*}{ Niobium } & 0.01 & - & - & - \\
\hline & 5.00 & & & \\
\hline
\end{tabular}

No analyses were made for niobium; however, other investigations $(8)$ have shown that it alloys quantitatively. 
The analyses of the protrusion samples indicated that this sample was representative of the ingot composition. Therefore, this method of sampling was chosen for the enriched-alloy runs. Based on the analytical data, the amount of molybdenum and zirconium charged was increased to obtain the desired composition in the enriched ingots.

The noble element or fissium composition of the enriched ingots is based on spectrophotometric analysis of about 20 percent of the alloy produced. The samples were taken from nine ingots and from the fuel pins cast from six other ingots. There is no discernible difference between the analysis of the ingots and that of the fuel pins. Although it is a more complicated and time-consuming procedure, the spectrophotometric method of analysis was used for the study of fissium composition in preference to emission spectrographic analysis, because the former method affords a higher degree of precision and accuracy. Samples from all the ingots and from all the batches of pins were analyzed by emission spectrographic techniques, however, for the purpose of determining the uniformity of distribution of the individual noble metals within the alloy.

The analytical results showed a recovery of 99 percent of the molybdenum in the enriched alloy as compared with the 96 percent recovery evidenced in the unenriched runs. No reason is apparent for this increase in alloying of the molybdenum. Consequently, the resultant ingots contain $2.54 \pm 0.05$ weight percent molybdenum instead of the desired 2.46 weight percent.

Ruthenium and palladium alloyed quantitatively. The resulting composition being $2.00 \pm 0.05$ weight percent ruthenium and $0.190 \pm 0.007$ weight percent palladium.

As in the unenriched alloy preparation runs, about 86 percent of the zirconium went into solution in the enriched alloys. The composition of the zirconium in the enriched alloy was $0.101 \pm 0.010$ as compared with the desired composition of 0.10 weight percent. Samples of five additional ingots were analyzed spectrophotometrically for zirconium.

No spectrophotometric analytical procedure was available for rhodium; therefore, the average value obtained by the emission spectrographic technique was used. This value was $0.26 \pm 0.01$ as compared with the desired value of 0.28 weight percent.

No analysis was made for niobium. However, other investigations (8) have shown that it would alloy quantitatively to the desired 0.01 weight percent. 
The resultant total noble metal composition of the alloys was $5.10 \pm 0.08$ weight percent, as compared with the 5.00 desired weight percent. This increase in composition, from 5.00 to 5.10 , is due to the higher than expected degree of solution of the molybdenum.

Trace element, carbon, and nitrogen analyses were not obtained for the individual ingots. However, they were obtained on the starting material and the fuel pins cast from the ingots. (9) These data show that there was no appreciable change in these constituents as a result of the alloy preparation of fuel-pin-casting operations. The carbon content averaged $125 \mathrm{ppm}$ and the nitrogen content averaged $20 \mathrm{ppm}$ in the fuel pins cast from the $F C$ ingots.

Isotopic Concentration

The specifications for the fuel alloy with respect to isotopic concentration are that $48.4 \pm 1.2$ atom percent of the uranium is present as $U^{235}$ and that the total of the $U^{234}$ and $U^{236}$ isotopes does not exceed one atom percent. These values are based on the alloy being 95 weight percent uranium and 5 weight percent noble metals. The results of the massspectrographic analyses were reported in weight percent of each isotope in total uranium with a precision of $t 1$ percent of the reported value. The value of $48.4 \pm 1.2$ atom percent $U^{235}$ is equal to $48.08 \pm 1.2$ weight percent of $\mathrm{U}^{235}$ in uranium. A third method of expressing the same values is as atom percent $\mathrm{U}^{235}$ in total alloy. The specifications converted to this basis require $42.99 \pm 1.06$ atom percent $U^{235}$ in total alloy. A comparison of the values of enrichment of the alloy with the specifications is shown in Table 5 .

Table 5

ENRICHMENT OF FUEL ALLOY

\begin{tabular}{|c|c|c|c|}
\hline & $\begin{array}{l}\text { Weight Per- } \\
\text { cent } U^{235} \text { in } \\
\text { Uranium }\end{array}$ & $\begin{array}{l}\text { Atom Per- } \\
\text { cent } U^{235} \text { in } \\
\text { Uranium }\end{array}$ & $\begin{array}{l}\text { Atom Per- } \\
\text { cent } U^{235} \text { in } \\
\text { Alloy }\end{array}$ \\
\hline Specifications & $48.08 \pm 1.2$ & $48.40 \pm 1.2$ & $42.99 \pm 1.06$ \\
\hline Analysis of Ingots & $48.09 \pm 0.10$ & $48.41 \pm 0.10$ & $42.88 \pm 0.23^{a}$ \\
\hline
\end{tabular}

a This value is based on $48.41 \pm 0.10$ atom percent $U^{235}$ in uranium and $5.10 \pm 0.08$ weight percent total noble metals in the alloy.

The homogeneity of ingot with respect to $U^{235}$ was tested on two ingots. Ingot FC-50 was sampled by the usual cast-protrusion method and in six other locations on the top, sides, and bottom of the ingot. Ingot FC-55 was sampled by the cast-protrusion method and by taking samples from the 
top, side wall, and bottom of the ingot. The analyses of these samples showed the same statistical variation as that found for the analyses of all the enriched ingot samples. No indication of segregation was found. The mass spectrographic results showed the presence of $0.58 \pm 0.02$ weight percent $\mathrm{U}^{234}$ in uranium, and $0.088 \pm 0.003$ weight percent $\mathrm{U}^{236}$ in uranium. This converts to $0.59 \pm 0.02$ and $0.088 \pm 0.003$ atom percent $\mathrm{U}^{234}$ and $\mathrm{U}^{236}$ in uranium. The total ( 0.675 atom percent) is less than the specified one (1) atom percent allowed for the two isotopes.

Table 6 summarizes the isotopic and chemical composition of the enriched ingots.

Table 6

\section{ISOTOPIC AND CHEMICAL COMPOSITION OF ENRICHED FISSIUM ALLOY}

Element
Uranium
$\mathrm{U}^{235}$
$\mathrm{U}^{234,236,238}$
$\mathrm{U}^{234}+\mathrm{U}^{236}$

Noble Metals

Molybdenum

Ruthenium

Rhodium

Palladium

Zirconium

Niobium ${ }^{\mathrm{a}}$
Weight Percent

Weight Percent

\begin{tabular}{ccc} 
Specified & & Obtained \\
$95.00 \pm 1.0$ & $94.90 \pm 0.10$ \\
$45.68 \pm 1.2$ & $45.64 \pm 0.10$ \\
$49.32 \pm 1.2$ & $49.26 \pm 0.10$ \\
$<1.0$ & $0.669 \pm 0.02$ \\
5.00 & $5.10 \pm 0.08$ \\
2.46 & $2.54 \pm 0.05$ \\
1.96 & $2.00 \pm 0.05$ \\
0.28 & $0.26 \pm 0.01$ \\
0.19 & $0.19 \pm 0.007$ \\
0.10 & $0.10 \pm 0.01$ \\
0.01 & \multicolumn{2}{c}{0.01}
\end{tabular}

Atom Percent

\begin{tabular}{ccc}
\hline Specified & & Obtained \\
\cline { 1 - 1 } $88.82 \pm 0.95$ & $88.58 \pm 0.28$ \\
$42.99 \pm 1.06$ & $42.88 \pm 0.23$ \\
$45.83 \pm 1.06$ & $45.70 \pm 0.23$ \\
$<1.0$ & & $0.675 \pm 0.02$ \\
11.18 & $11.42 \pm 0.28$ \\
5.67 & $5.87 \pm 0.10$ \\
4.25 & $4.33 \pm 0.12$ \\
0.60 & $0.56 \pm 0.02$ \\
0.39 & $0.39 \pm 0.02$ \\
0.25 & $0.25 \pm 0.02$ \\
0.02 & \multicolumn{2}{c}{0.02}
\end{tabular}

a No analysis obtained for niobium; quantitative alloying was assumed.

Effect of Time and Pour Temperature on Yield

Studies (1) made with unirradiated material and tracer-level irradiated fissium indicated that the required conditions of liquation of the melt in the melt-refining process were 3 to $4 \mathrm{hr}$ at $1400 \mathrm{C}$. Since the alloy preparation runs were being utilized to provide operating experience with the equipment, the majority were made at these run conditions.

In preliminary runs (DL 5 and 6) the melts were liquated at $1400 \mathrm{C}$ for only one hour. The results showed that one hour was adequate for alloying the noble metals with the uranium. All subsequent runs were made with longer liquation times. Table 7 shows the effect of liquation time at $1400 \mathrm{C}$ on the pour yield. 
Table 7

\section{EFFECT OF LIQUATION TIME \\ ON YIELD}

$\begin{array}{cc}\begin{array}{c}\text { Time at } 1400 \mathrm{C} \\ (\mathrm{hr})\end{array} & \text { Yield } \\ 1 & 97.2 \\ 3 & 96.9 \\ 4 & 96.6\end{array}$

These runs showed that the yield varied, but not appreciably, with liquation times between $\mathrm{l}$ and $4 \mathrm{hr}$.

A series of runs was made to determine the effect of pouring temperature on yield. In these runs the alloys were liquated for $3 \frac{1}{2} \mathrm{hr}$ at $1400 \mathrm{C}$. The results are shown in Table 8 .

Table 8

EFFECT OF POUR TEMPERATURE ON YIELD

\begin{tabular}{cc}
$\begin{array}{c}\text { Pour Temp. } \\
\text { (C) }\end{array}$ & $\begin{array}{c}\text { Avg Yield } \\
(\%)\end{array}$ \\
\cline { 1 - 1 } & $\begin{array}{c}1200 \\
1300\end{array}$ \\
1400 & 95.2 \\
& 96.1 \\
& 96.4
\end{tabular}

\section{Crucible Degassing}

Of the 18 runs of the DL series that were liquated between 3 and $4 \mathrm{hr}$ at $1400 \mathrm{C}$, seven of the crucibles were degassed prior to use and the remaining 11 were not. Crucibles were degassed at temperatures varying from 500 to $1500 \mathrm{C}$, at times from 2 to $6 \mathrm{hr}$ and for pressures from 1 to $1 \times 10^{-3} \mathrm{~mm}$. The degassing of the crucibles had no appreciable effect on the pouring yield. The average yield was $96.9 \pm 0.4$ percent for the runs using the degassed crucibles and $96.7 \pm 0.4$ percent for the runs using the non-degassed crucibles.

The condition of the furnace and components did have an effect on the yield. Before making the runs with unenriched uranium, the furnace was degassed if it had been allowed to stand open prior to the run. The yields increased by about $\frac{1}{2}$ percent for each subsequent run for the next 4 to 5 runs. The average yield increased gradually with the use, and 
presumably with the degassing, of the furnace components. The average yield for the first $10 \mathrm{FC}$ runs was 96 percent and increased gradually and steadily to an average of 97.3 percent for Runs Number 70 to 86 .

Pin Remelt Yields

The average yield for the enriched pin-remelt runs made in nondegassed crucibles was $92.3 \pm 1.3$ percent. Eight runs were made in degassed crucibles. The average yield for these runs was $94.0 \pm 0.9$ percent. It appears that degassing a crucible has an effect on the pour yield when pins are used. This is probably due to the many-fold increase in the surface-to-volume ratio of the pins as compared with the bulk metal used in the alloy preparation runs, in which no appreciable effect on pouring yields was observed.

\section{CONCLUSIONS}

The results of these runs showed that 85 percent of the zirconium and 96 to 100 percent of the molybdenum went into solution. The remaining elements (ruthenium, rhodium, palladium, and niobium) alloyed quantitatively. The data also showed that complete homogenization of the constituents took place in one hour at $1400 \mathrm{C}$. The method of sampling, protrusion casting, and the method of analysis, emission spectrography, were also proven. Degassing the crucibles prior to use in alloy preparation did not affect the pour yield as compared with the use of nondegassed crucibles. However, degassing the crucibles for the pin remelt runs increased the pour yield by about 1.5 percent. Decreasing the pouring temperature from 1400 to $1200 \mathrm{C}$ decreased the pour yield from 96.4 percent to 95.2 percent.

Many equipment modifications and improvements were suggested and made during these runs. However, these changes were minor in scope, and, in general, the equipment proved to be very satisfactory.

\section{ACKNOW LEDGMENTS}

The author wishes to acknowledge the assistance received from the following members of the Chemical Engineering Division: M. Levenson and J. H. Schraidt for assistance in development and coordinating the program; W. E. Miller, V. N. Thelen, T. F. Cannon, R. C. Paul, and A. L. Chandler for aid in the operation of the equipment; R. P. Larsen and L. E. Ross for spectrophotometric analytical assistance; and J. Goleb of the Chemistry Division for emission spectrographic data. 


\section{REFERENCES}

1. Feder, H. M., Chellew, N. R., and Ader, M., Interim Report. Purification of Nuclear Fuels by Melting in Refractory Oxide Crucibles, ANL-5255 (March 15, 1954).

2. Burris, L., Feder, H. M., Lawroski, S., Rodger, W. A., and Vogel, R. C., The Melt Refining of Irradiated Uranium: Application to EBR-II Fast Reactor Fuel. Nuclear Science and Engineering, 6(6), 493 (Dec 1959).

3. Burris, L., Jr., and Dillon, I. G., Estimation of Fission Product Spectra in Discharged Fuel from Fast Reactors, ANL-5742 (July 1957).

4. Levenson, M., et al., The Pyrometallurgical Process and Plant for EBR-II, Proceedings of Second United Nations International Conference on Peaceful Uses of Atomic Energy, Geneva, Switzerland, 17,414 (1958).

5. Hampson, D. C., Schraidt, J. H., Malecha, R. F., Equipment for Purification of Spent Reactor Fuel by Melt Refining, Proceedings of the Sixth Hot Laboratories and Equipment Conference, Chicago, Illinois (1950), p. 54.

6. Graae, J. E. A., Hampson, D. C., Pollack, I., Levenson, M., Schraidt, J. H., and Bernstein, G. J., A Radiation Stable Heavy Duty Electromechanical Manipulator, Proceedings of the Eighth Conference on Hot Laboratories and Equipment, San Francisco, California, USAEC Report TID-7599, Book l (1960), p. 239.

7. Bernstein, G. J., Graae, J. E. A., Levenson, M., and Schraidt, J. H., Design for a Remotely Operated Facility for High Temperature Process ing of Spent Reactor Fuel, Proceedings of the Sixth Hot Laboratories and Equipment Conference, Chicago, Illinois (1958), p. 39.

8. Macherey, R. E., Bean, C. H., Carson, N. J. Jr., and Lindgren, J. R., Manufacture of Fuel Plates for the Experimental Boiling Water Reactor, ANL-5629.

9. Shuck, A. B., Carson, N. J. Jr., and Jelinek, H. F., The Manufacture of EBR-II, Core I Fuel Pins, ANL-6274. 